\title{
Natural heritage values and comparative analyses of Kanas, China
}

\author{
ZhaoPing YANG ${ }^{1 *}$, Xiaolei ZHANG ${ }^{1}$, Feng $\mathrm{DI}^{1,2}$, Geoffrey WALL ${ }^{3}$, XinYu LIU ${ }^{1,2}$, Rui SHAO ${ }^{1,2}$ \\ ${ }^{1}$ Xinjiang Institute of Ecology and Geography, Chinese Academy of Sciences, Urumqi 830011, China; \\ ${ }^{2}$ Graduate University of Chinese Academy of Sciences, Beijing 100049, China; \\ ${ }^{3}$ University of Waterloo, Waterloo, Ontario N2L 3G1, Canada
}

\begin{abstract}
Kanas is a National Nature Reserve and National 5A Scenic Area, and it is also high on China's National Natural Heritage List. In this paper, with an integrated analysis and comparative geographical approach, the genesis and current features of the Kanas landscape are analyzed systematically according to the criteria for outstanding universal values that must be met for designation by the United Nations as World Natural Heritage. It is concluded that Kanas has outstanding universal values in geosciences, biology and aesthetics. Through comparison with other World Natural Heritage sites of the same geological types, in the same biogeographic zone and in the same latitude, it is concluded that Kanas meets criteria vii, viii, ix and $x$ for designation as World Natural Heritage. Thus, this work establishes a scientific foundation for nomination of Kanas for such a status.
\end{abstract}

Keywords: natural landscape characteristics; heritage value; comparative analyses; Kanas of Xinjiang

\section{Introduction}

Natural heritage is formed through the evolution of natural processes and it possesses both scientific and aesthetic values (Liu et al., 2009). It includes UNESCO (The United Nations Educational, Scientific and Cultural Organization) World Natural Heritages sites as well as the natural components of the mixed World Natural and Cultural Heritage sites. It also includes Chinese National Natural Heritage sites, National Nature Reserves, Scenic Spots, National Forestry Parks, the habitats of rare and endemic species, important geologic relicts and so on (Chen et al., 2004; Zhang et al., 2004; Zhang, 2008). The functions of natural heritage are to support society and economy through the provision of ecological services, maintaining biodiversity, tourism, perpetuating scenic beauty and providing resources for environmental education. It also plays an important role in the research of geosciences, species evolution and biodiversity. According to UNESCO (2008), natural values can be reduced to four elements: geosciences, species evolution, natural beauty and the habitats of creatures (Liu, 2006). The prominent value is the core content of
World Natural Heritage application, protection and management (Zhang et al., 2006; Hazen, 2008; Li et al., 2008; Luo et al., 2008; Chen et al., 2009; Xu et al., 2009). Authenticity and integrity are criteria for evaluating natural heritage and also key to protecting it (Zhang et al., 2003).

\section{Study area and methods}

\subsection{Study area}

Kanas is located within Bruqin County of Altai (also known as Altay) Prefecture in Xinjiang of China, and adjacent to Kazakstan, Russia and Mongolia. In 1986, it became a National Nature Reserve, with an area of 2,200 $\mathrm{km}^{2}$ (Fig. 1). Kanas is the only region in China where the headwaters flow to the Arctic Ocean and it is the only zone of European Siberian taiga forests, flora and fauna in China, as well as the southern distribution limit of Siberian taiga forest. Kanas is also the only place where the Mongolian Tuwa people live in China. During its long-term evolution, the advanta-

Received 2010-04-15, accepted 2010-05-31

doi: 10.3724/SP.J.1227.2010.00197

* Corresponding author: ZhaoPing YANG (E-mail: yangzp@ms.xjb.ac.cn) 


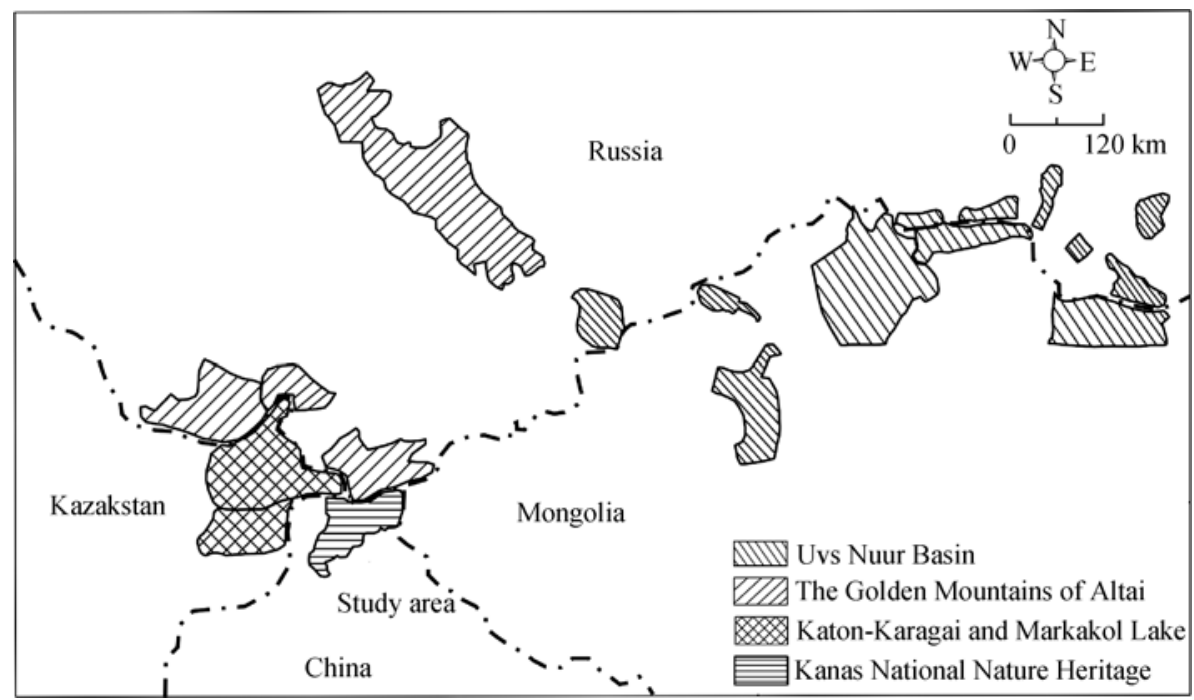

Fig. 1 The distribution of the natural heritage in the Altai's geographic location

geous geographic location and various natural elements have resulted in the formation of special natural landscape and biodiversity in the Kanas region, which endows it with the potential to be a World Natural Heritage site (Liu et al., 2007; Di et al., 2010). In 2006, Kanas was included on the Tentative List of Chinese Natural Heritage and the program to apply for World Heritage designation was formally initiated in 2009.

\subsection{Methods}

In the paper, we used comprehensive method of analysis which is based on the predominant factors of geological structure, glacial landforms, biodiversity and natural landscape, etc., analyzing systematically the genesis and current features of the Kanas landscape. We also used the comparative geographic analysis method, which is based on the similar geologic type, the same biogeographical zone, and the natural landscape in the same latitude, comparing Kanas systematically with similar World Natural Heritage sites.

\section{Results and discussion}

\subsection{The charactersitics of the heritage}

3.1.1 Typical and complicated geological tectonics

From the perspective of geology, the Kanas region is located at the junction of the Altai and the Junggar fold systems, which is made up of the anterior and lower Paleozoic Cambrian-Ordovician granites, gneisses and mud schist etc. The former fold system is at the southwest edge of the Siberia plate and the latter is at northern Zaysan. The Kanas region was formed by the Wuliegai synclinal fold belt and the Fuyun anticlinal fold belt of the Altai fold zone, which combined to result in a huge fold anticlinorium during the early Hercynian period. In Kanas region, the tectonic system arcs in a northwest-southeast direction, projecting to the south. The mountain fold belt first appeared during the early Caledonian tectonic movement, when an orogenic zone resulted from the collision between the Altai-Mongolia block and the Siberian ancient continent, and a complicated tectonic landform zone of folds and faults was formed. Intense crustal movement at the end of the Hercynian period caused Altai to change from an ocean into a continent and the basic outline of the ancient Altai Mountains was formed at the end of Permian period. After that, the mountains were leveled to a peneplain. Then, they were uplifted to varying extents and multi-level planation resulted from long-term erosion. The neotectonic movement created the current Altai Mountains with their alternating peaks and valleys, great relief amplitude and multi-level terrace pattern. From the Neogen to the early Quaternary, by glaciations as well as fluvial erosion by melting glacial water, the modern geographical pattern was formed, including the glacial geomorphology, fluvial geomorphology, lacustrine geomorphology, etc.

3.1.2 Well developed and preserved glacial geomorphology

Several glaciations occurred to the China Altai during the Quaternary and multiple glacial erosion features 
and accumulation landforms were created. Kanas region is located on the south slope of Youyi peak (4,374 $\mathrm{m}$ above sea level) which is the main peak of the Altai Mountains. This region is the largest centre of glaciation in the Altai Mountains and it has recorded the complete sequence of the glacial geography since the mid-Pleistocene. Key features of the glacial geomorphology will be mentioned briefly. The scale of modern glaciers is tremendous and the area of glaciers in the Kanas region accounts for nearly half of the total area of Youyi Peak and is the largest among the whole Altai Mountains (Wang et al., 1983). The types of glaciers are varied and typical, such as converging valley glaciers, dendritic valley glaciers and ice caps (Yi et al., 1994). There are three prominent groups of cirques, one totally covered by plants, hollow cirques, and modern glaciers. Together, they reflect the stages and characteristics of the glacial shrinkage and vegetation expansion. Nunataks and knife-edges, as well as huge glacial grooves, have widely developed, and the bedrocks of the glacial pavement and sheep-back rocks (roches moutonnee) outcrop frequently (Liu et al., 1983). The glacial lakes are distributed like lines of pearls. The relatively large ones are Kanas Lake, White Lake, Black Lake and Double Lakes (Feng, 1983). They reflect the stages and extent of the glacial shrinkage. Glacial sediments are widespread and include moraine hillocks and glacial boulders. There are three intact moraine hillocks along the Kanas valley. From high to low, they are the terminal moraines of the Kanas glaciers, the moraine hills at the outlet of White Lake and the terminal moraine hillocks at the outlet of Kanas Lake.

\subsubsection{Important biodiversity}

The biological features in Kanas region are as follows: (1) Vegetation types are varied. The vegetation in Kanas region can be divided into 3 classes, 9 types, 20 subtypes and 42 floras, with a complete vertical structure. There is prominent biodiversity and the wild vascular plants in Kanas region consist of 88 families, 416 genus and 1,172 species and are the most abundant on the south slope of the Altai Mountains. (2) There are many rare and endangered species in the nominated area. The nominated sites have 2 species of endangered plants identified by IUCN (International Union for the Conservation of Nature and Natural Resources, 2003) for protection. Eight species of plants are listed in the CITES (Convention on International Trade in Endangered Species, 2007) Appendix I, Appendix II and Appendix III of the International Trade Convention of Endangered Animals and Plant Species. They are all Orchidaceae: Epipogium aphyllu, Epipactis helleborine, Spiranthes sinensis, Goodyera repens, Coeloglossum viride, Orchis baltica, Orchis 1atifolia and Orchis fuchsia. Two species of plants are listed in the National Protection List for Endemic Plants, i.e. Nymphaea candida and Agropyron mongolicum. There are 71 species of animals identified by IUCN for protection and 73 species of animals are listed by CITES for protection. There are also 13 species of animals under First-level National Protection, such as Uncia uncia, Martes zibellina altaica, Culo gulo gulo, Capra sibirica and Castor beavers, and 57 species of animals under Second-level National Protection, such as Ovis ammon, Lynx lynx, Ursus arctos, Lepus timidus, Martes foina etc. (3) The transition between species in this region is remarkable. The flora and fauna of Siberia and Xinjiang overlap through this region. Many species of fauna and flora in Siberia reach the limit of their distribution zone in southernmost. The flora in this region is typically characteristic of a temperate zone. Native plants and the plants of mid-Asia and west Asia overlap relatively frequently but the mixing with the East Asian and North American plants is relatively rare. The avifauna composition in this region, which is the convergence point between western and eastern avifauna, is complicated, such as Perdix perdix and Perdix dauuricae, Streptopelia turtur and Streptopelia orientalis, Syrrhaptes orientalis and Syrrhaptes paradoxus, etc. This region is also where the east and the west migrations diverge. Some species cross each other in the migration season, e.g. Carduelis carduelis, Parus major and Corvus corone. With respects to the composition and distribution of mammals, the northern and north-circling types account for $33.4 \%$ of the total number, while the northeastern, mid-Asian and highland types make up the rest. This indicates that the mammal fauna of this region is characteristic of the northern taiga forest, as well as the transition from northern to mid-Asian types.

3.1.4 Integrated and diverse natural landscapes

Kanas region possesses many kinds of natural wonders, including glaciers, snowfields, high mountains, 
rivers, lakes, forests, grasslands, wetlands, granite geomorphology and so on (Di et al., 2009). The glaciers on Youyi Peak in the Kanas region are grand and spectacular. Several ice tongues descend the peaks. They are majestic and can be regarded as natural wonders. There are impressive lakes, such as Kanas Lake, White Lake, Double Lakes and Black Lake, as well as the winding Dragon valley, Moon valley and Fairy valley along the Kanas River. The verdant forests along the banks are reflected in the rivers, forming an essential landscape element in Kanas. The taiga contrasts with the snow-capped mountains in the spring and, in summer, and it is reflected in the water, in shades of green. In the fall, yellow and red colors are interwoven as the leaves change their hue. In the winter mists, the branches reflect like silver jewelry in the icy water. In spring, the meadows turn green and the flowers add their colors. Herds and flocks, and clusters of yurts turn the alpine pastures into a harmonious natural and human mosaic. Kanas Lake is famous for its changing colors. Because the white granitic powders of glaciers dissolve into the water, the rivers and lakes appear to be pure jade. The morning mists, changing skies, evening shadows, rainbows, snow-capped pines, natural snow sculptures and glacial waterfalls enrich the natural landscape of Kanas. The native Kazak and Mongolian Tuwa people migrate among the waters and the grasslands, living their special folk customs. The particular nomadic life is gentle on the environment so that the authentic nature has been well preserved in this region. The historical remnants of the nomadic culture, including stone human statues, petrograms and ancient graves, have also been preserved in an environment in which human beings and nature are in harmony.

\subsection{The values of the natural heritage}

\subsubsection{Values of geoscience}

The Altai Mountains are the key accumulation zone of glaciers in the world. Kanas region is where the south slope of Youyi Peak is located and the glacial area in this region accounts for over $40 \%$ of the total area around Youyi Peak. The glaciers in this region are the most prominent representatives of the Altai Mountain glaciers and are the key to research on the Quaternary glacial movements of the Altai Mountains. Both mod- ern and well-preserved ancient glacial remnants exist. The area can be regarded as an encyclopedia and natural museum of mountainous glacial geography. The post-Quaternary glacial evolution has been completely recorded in this region and provides invaluable information for understanding the impact of global warming on the mountainous ecological system. Thus, this region has high scientific value for research on glacial geography and climate change.

\subsubsection{Values of biological diversity}

The Altai Mountains are a key area of global biodiversity. They are located in Udvardy's (1975) “Altai Highlands” Biogeographical Province and also represent the Altai-Sayan Montane Forests within the system of 200 global biota recognized by WWF (World Wildlife Fund). This region has been the main habitat for many endemic and endangered plants and animals. Kanas region is a typical representative of the south slope of the Altai Mountains and the natural distribution of Siberian flora and fauna reaches their southernmost limit in this region, which is the ecotone between the temperate desert and Siberian fauna and flora. It is also the transition zone from warm temperate forest to warm temperate grassland and deserts, and it is a region where flora and fauna have evolved distinctively. This region is characterized by biodiversity, heterogeneity and sudden environmental disturbances. These biological communities contain species groups that are well-suited to particular environments and reflect differential evolution. If these species groups were impaired, the losses would be incalculable.

\subsubsection{Aesthetic values of the natural landscape}

Kanas region possesses a diversity of landscape features, such as glaciers, snowfields, high mountains, rivers, lakes, forests, grasslands and wetlands, as well as special folk customs. These landscapes are of multiple types and are characterized by high quality, great heterogeneity, stunning vistas and rich folk cultures. The unique natural landscape and multiple folk cultures have fostered aesthetics of extremely high value. It is the type example of the Altai Mountains' beautiful natural and human landscapes, and it is a remarkable exemplification for the aesthetic values of an integrated natural and human mountainous landscape. 


\subsection{Comparative analyses of the natural heritage values}

3.3.1 Comparison with other similar geological heritages

A report by IUCN entitled Geological World Heritage: A Global Framework (Thorsell et al., 2002; Dingwall et al., 2005; Zhao et al., 2007) listed 13 kinds of geological types with universal values that focus on glaciers. They are tectonics, volcanoes, mountains, stratigraphic sites, fossils, fluvial/lacustrine and deltaic systems, karst, coastal systems, reef-island, glaciers, Ice Ages, arid and semiarid deserts, and meteorite impact (Jim Thorsell and Larry Hamilton, 2002; Zhao et al., 2007). There are 13 items of world heritage which have been nominated for outstanding universal values based on glaciers (Table 1 and Fig. 2). There are also 7 items of world heritage which have been nominated for other reasons but also possess significant elements of glaciers (Table 2).

Of the 13 World Heritage sites placed on the World Heritage List for the value of their glaciers, Los Glaciares National Park of Argentina, The Laponian Area of Sweden, Ilulissat Icefjord of Denmark, the Natural System of Wrangel Island Reserve of Russia, and Heard and McDonald Islands of Australia all focus on oceanic glaciers. The glacial types of these heritage sites are not analogous to those of Kanas and no direct comparisons can be made between them. The glaciers of Rwenzori Mountains National Park of Uganda, Mount Kenya National Park/Natural Forest of Kenya and Sangay National Park of Ecuador are all tropical mountainous glaciers. The environments of the above-mentioned heritage sites are very different from that of Kanas, and no direct comparisons can be made between them. Sagarmatha National Park of Nepal, Nanda Devi and the Valley of Flowers National Park of India, and Huanglong Scenic and Historic Interest Area of China are attributed to the Qinghai-Tibet plateau mountainous glacier region. The tectonics and surrounding environment of these sites are distinctive in comparison with Kanas. Waterton-Glacier International Peace Park, which is possessed together by Canada and the USA, is the first International Peace Park in the world, and Swiss Alps Jungfrau-Aletsch of Switzerland is where the most prominent glacial erosion has occurred in the Alps. These two sites are in the same latitude as Kanas, then the glaciers of former two sites are warm temperate mountainous glaciers and the later is temperate mountainous glacier. Furthermore, the glaciers of Waterton-Glacier Interna-

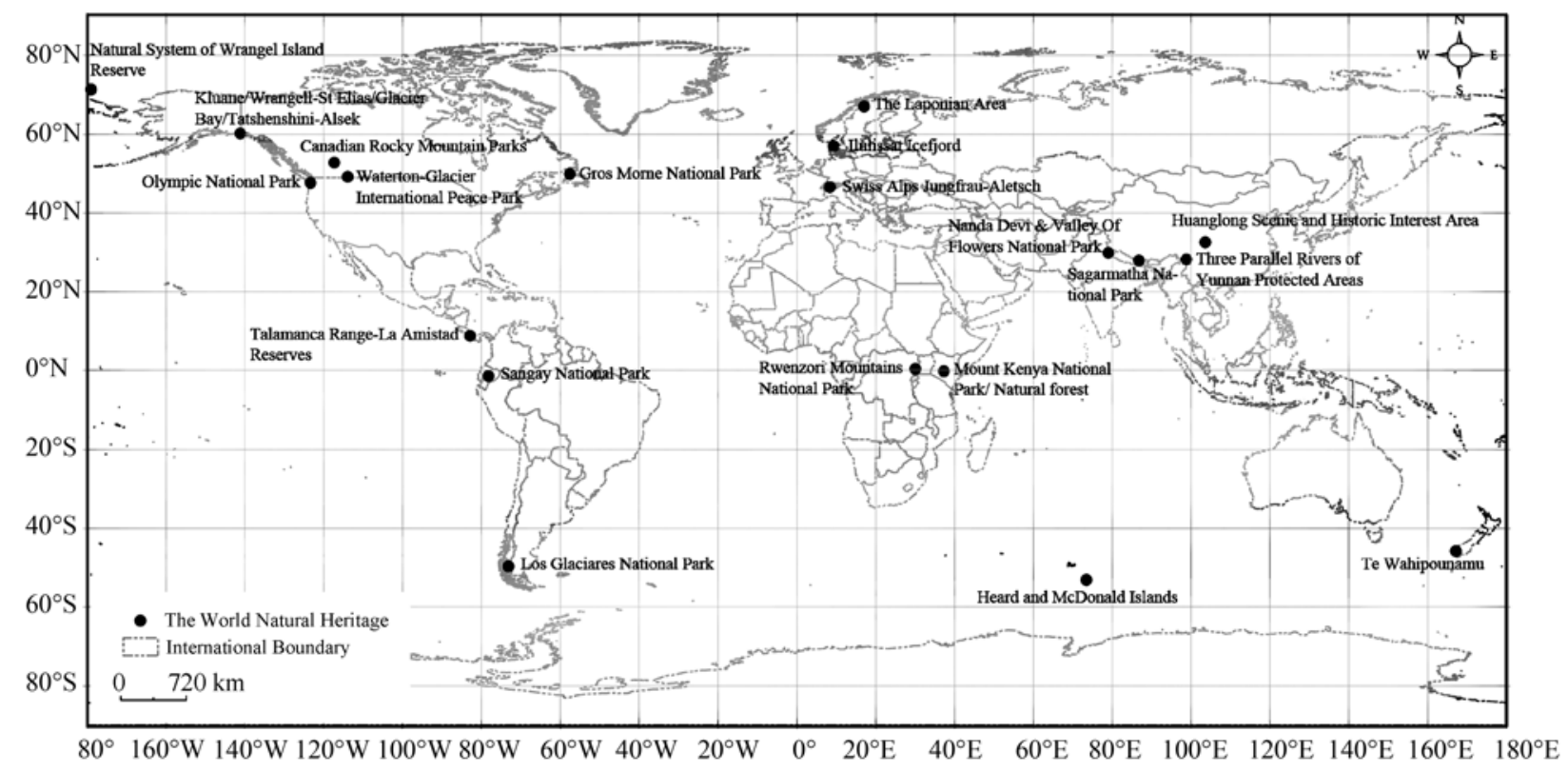

Fig. 2 The distribution of World Heritage sites that possess outstanding universal values based on glaciers 
Table 1 Outstanding universal values of glaciers of 13 World Heritages

\begin{tabular}{|c|c|c|c|c|c|c|}
\hline Name & Country & Criteria & Year & Area $\left(\mathrm{hm}^{2}\right)$ & Altitude (m) & Features \\
\hline $\begin{array}{l}\text { Los Glaciares National } \\
\text { Park }\end{array}$ & Argentina & vii, viii & 1981 & 445,900 & $200-3,375$ & $\begin{array}{l}\text { It is part of the third largest glacial landmass in } \\
\text { the world }\end{array}$ \\
\hline Sangay National Park & Ecuador & vii, viii, ix, $\mathrm{x}$ & 1983 & 271,925 & $800-5,319$ & $\begin{array}{l}\text { It has outstanding natural beauty, two snow- } \\
\text { capped active volcanoes and a range of ecosys- } \\
\text { tems from the tropical rainforests of the Ama- } \\
\text { zon basin to mountain glaciers }\end{array}$ \\
\hline The Laponian Area & Sweden & $\begin{array}{l}\text { c iii, v/n vii, } \\
\text { viii, ix }\end{array}$ & 1996 & 940,000 & $165-2,089$ & $\begin{array}{l}\text { The area is known as a textbook example of } \\
\text { glacier-related geomorphology }\end{array}$ \\
\hline $\begin{array}{l}\text { Heard and McDonald } \\
\text { Islands }\end{array}$ & Australia & viii, ix & 1997 & 36,500 & $0-2,745$ & $\begin{array}{l}\text { Eighty percent of Heard Island is glaciated, } \\
\text { with ice up to } 150 \mathrm{~m} \text { depth and } 12 \text { main gla- } \\
\text { ciers extending from } 2,745 \mathrm{~m} \text { to sea level }\end{array}$ \\
\hline $\begin{array}{l}\text { Swiss Alps Jungfrau- } \\
\text { Aletsch }\end{array}$ & Switzerland & vii, viii, ix & $\begin{array}{l}2001 \\
2007\end{array}$ & 82,400 & $567-4,518$ & $\begin{array}{l}\text { They are the most extensively glaciated moun- } \\
\text { tains in Switzerland and contain the largest } \\
\text { glacier in Eurasia }\left(35,000 \mathrm{hm}^{2}\right)\end{array}$ \\
\hline Ilulissat Icefjord & Denmark & vii, viii & 2004 & 4,024 & $0-1,200$ & $\begin{array}{l}\text { It is an outstanding example of an actively } \\
\text { calving ice sheet }\end{array}$ \\
\hline $\begin{array}{l}\text { Sagarmatha National } \\
\text { Park }\end{array}$ & Nepal & vii & 1979 & 114,800 & $2,845-8,848$ & $\begin{array}{l}\text { This majestically scenic mountain park of } \\
\text { snow-covered peaks, gorges and glaciers domi- } \\
\text { nated by the highest mountain on the Earth } \\
\text { (Sagarmatha) is geologically interesting and its } \\
\text { wilderness values are outstanding }\end{array}$ \\
\hline $\begin{array}{l}\text { Nanda Devi and Valley } \\
\text { of Flowers National Park }\end{array}$ & India & vii, $\mathrm{x}$ & $\begin{array}{l}1988 \\
2005\end{array}$ & 71,783 & $1,900-7,817$ & $\begin{array}{l}\text { It is one of the most spectacular wilderness } \\
\text { areas in the Himalayas }\end{array}$ \\
\hline $\begin{array}{l}\text { Huanglong Scenic and } \\
\text { Historic Interest Area }\end{array}$ & China & vii & 1992 & 70,000 & $1,700-5,588$ & $\begin{array}{l}\text { It contains three bearing glaciers, seven over } \\
5,000 \mathrm{~m} \text { high and all snow-covered for much of } \\
\text { the year }\end{array}$ \\
\hline $\begin{array}{l}\text { Rwenzori Mountains } \\
\text { National Park }\end{array}$ & Uganda & vii, $\mathrm{x}$ & 1994 & 99,600 & $1,670-5,109$ & $\begin{array}{l}\text { It includes the third, fourth and fifth highest } \\
\text { peaks in an alpine highland of glaciers, snow- } \\
\text { fields and lakes in Africa }\end{array}$ \\
\hline $\begin{array}{l}\text { Waterton-Glacier Inter- } \\
\text { national Peace Park }\end{array}$ & Canada/USA & vii, ix & 1995 & 457,614 & $972-3,190$ & $\begin{array}{l}\text { It is the world's first International Peace Park. } \\
\text { The Park has no active glaciers but does con- } \\
\text { tain permanent snowfields }\end{array}$ \\
\hline $\begin{array}{l}\text { Mount Kenya National } \\
\text { Park/Natural forest }\end{array}$ & Kenya & vii, ix & 1997 & 142,020 & $3,100-5,199$ & $\begin{array}{l}\text { There are eleven remnant glaciers on the moun- } \\
\text { tain, some } 20 \text { glacial tarns of varying sizes and } \\
\text { numerous glacial morainal features between } \\
3,950 \mathrm{~m} \text { and } 4,800 \mathrm{~m}\end{array}$ \\
\hline $\begin{array}{l}\text { Natural System of } \\
\text { Wrangel Island Reserve }\end{array}$ & $\begin{array}{l}\text { Russian } \\
\text { Federation }\end{array}$ & $i x, x$ & 2004 & $1,916,300$ & $0-1,093$ & $\begin{array}{l}\text { Never having been glaciated, it is an out- } \\
\text { standing example of the continuous evolution- } \\
\text { ary development of a range of natural Arctic } \\
\text { systems since Mesozoic times }\end{array}$ \\
\hline
\end{tabular}

Data sources: http://whc.unesco.org/ and http://unep-wcmc.org/.

tional Peace Park and Swiss Alps Jungfrau-Aletsch are both oceanic mountain glaciers, while the glaciers of Kanas are Eurasian inland mountain glaciers and it is the centre of glaciation in Altai. It stands for the inland mountain glaciers in the middle and high latitudes in the world.

Of the seven World Heritage sites that have important geological characteristics of glaciers but were inscribed on the World Heritage List on the basis of other values (Table 2), some are oceanic glaciers while others are temperate mountain glaciers. Kluane/ Wrangell-St Elias/Glacier Bay/Tatshenshini-Alsek is owned by Canada and USA and is the world's largest non-polar icefield; Olympic National Park of USA is composed of three eco-systems jokul temperate rainforest and seashore; Talamanca Range-La Amistad Reserves, owned by Costa Rica/Panama, is the only area in Central America to show signs of glaciation; and Te Wahipounamu in New Zealand has entirely intact glacial landforms. Of the temperate glaciers, the Three Parallel Rivers of Yunnan Protected Area is the southernmost glacier in China and is claimed to be the lowest glacier in the northern hemisphere at that latitude $\left(28^{\circ} \mathrm{N}\right)$; Canadian Rocky Mountain Parks and Gros Morne National Park in Canada are at the same latitude as Kanas, but their glaciers are not mountain glaciers in the arid region. Compared with the most important distribution zone of glaciers in Altai Moun- 
Table 2 Several World Heritage sites with other values except for their important glaciers' characteristics

\begin{tabular}{|c|c|c|c|c|c|c|}
\hline Name & Country & Criteria & Year & Area $\left(\mathrm{hm}^{2}\right)$ & Altitude (m) & Features \\
\hline $\begin{array}{l}\text { Kluane/Wrangell-St } \\
\text { Elias/Glacier Bay/ } \\
\text { Tatshenshini-Alsek }\end{array}$ & Canada/USA & vii, viii, ix, $\mathrm{x}$ & 1979 & $9,839,121$ & $0-5,950$ & $\begin{array}{l}\text { It is the world's largest non-polar icefield, the long- } \\
\text { est valley glacier and the largest piedmont glacier } \\
\text { on the continent }\end{array}$ \\
\hline $\begin{array}{l}\text { Olympic National } \\
\text { Park }\end{array}$ & USA & vii, ix & 1981 & 369,659 & $0-2,428$ & $\begin{array}{l}\text { Ancient } 1,000 \mathrm{~m} \text { thick continental ice sheets trans- } \\
\text { ported granite erratics from British Columbia } 200 \\
\text { km north }\end{array}$ \\
\hline $\begin{array}{l}\text { Talamanca Range-La } \\
\text { Amistad Reserves }\end{array}$ & $\begin{array}{l}\text { Costa } \\
\text { Rica/Panama }\end{array}$ & vii, viii, ix, $x$ & 1983 & 567,845 & $50-3,819$ & $\begin{array}{l}\text { During the Quaternary, glaciers carved cirque lakes } \\
\text { and valleys with sides of over } 60^{\circ} \text { on the slopes of } \\
\text { Cerro Chirripó, the only area in Central America to } \\
\text { show signs of glaciation }\end{array}$ \\
\hline $\begin{array}{l}\text { Canadian Rocky } \\
\text { Mountain Parks }\end{array}$ & Canada & vii, viii, ix & 1984 & $2,021,000$ & $900-3,747$ & $\begin{array}{l}\text { The Columbia Icefield is the largest in North } \\
\text { America's sub-arctic interior and is considered the } \\
\text { hydrographic apex of North America }\end{array}$ \\
\hline $\begin{array}{l}\text { Gros Morne National } \\
\text { Park }\end{array}$ & Canada & vii, viii & 1987 & 180,500 & $0-806$ & $\begin{array}{l}\text { A number of steep-sided glacial valleys cut through } \\
\text { the Long Range scarp face, forming deep oligotro- } \\
\text { phic lakes, with vertical cliffs up to } 685 \text { m high }\end{array}$ \\
\hline Te Wahipounamu & New Zealand & vii, viii, ix, $\mathrm{x}$ & 1990 & $2,600,000$ & $0-3,764$ & The glacial landforms remain almost entirely intact. \\
\hline $\begin{array}{l}\text { Three Parallel Rivers } \\
\text { of Yunnan Protected } \\
\text { Areas }\end{array}$ & China & vii, viii, ix, $x$ & 2003 & 939,441 & $760-6,740$ & $\begin{array}{l}\text { There are notable examples of Quaternary alpine } \\
\text { and modern glaciers, such as Mingyongqia, where } \\
\text { is the southernmost glacier in China }\end{array}$ \\
\hline
\end{tabular}

Data sources: http://whc.unesco.org/ and http://unep-wcmc.org/.

tain-Mount Youyi and Mount Kuitun located in Russia, Mongolia and Kazakstan, the Kanas region is an area with the most developed and representative glaciers in the whole Altai Mountains. From this point of view, it is irreplaceable.

3.3.2 Contrast with the World Heritage of the same Biogeographical Provinces

Udvardy's Biogeographic system further classifies the world into 14 ecosystem types (1975). Udvardy's Biogeographic Realms are subdivided into 193 Biogeographical Provinces. There are 2 World Heritage sites in Udvardy's Altai Highlands Biogeographic Province (Magin, 2005) (Table. 3 and Fig. 1).

To contrast Kanas with the world natural heritage Golden Mountains of Altai in Russia, which meets criteria $\mathrm{x}$ for designation as World Natural Heritage. Kanas region represents the characteristics of physical geography and mountainous ecosystems on the south slope of the Altai Mountains and reflects the transition from taiga forest to temperate desert. Golden Moun- tains of Altai represents the north slope of the Altai Mountains, and reflect the transition from taiga forest to tundra. A complete physical geographic unit and mountainous ecosystem will never exist without the integration of both. Hence, Kanas is an indispensable part of the Altai Mountains ecosystem. Furthermore, a complete range of types and the intricate combination of landscape features, such as glaciers, snowfields, rivers, lakes, forests, grasslands, wetlands, etc. in Kanas which are not included in the Golden Mountains of Altai in Russia. This means the aesthetic values of the Kanas are superior. Kanas and the Golden Mountains of Altai in Russia express the outstanding and prevalent values as natural heritage in different ways.

To contrast Kanas with Uvs Nuur Basin which is shared by Mongolia and Russia, the former is the ecological transitional region from the temperate desert in the Junggar Basin to the fauna and flora combination in Siberia, and the latter is partly located in Altai

Table 3 Two World Heritage sites of Altai Highlands Biogeographic Province

\begin{tabular}{|c|c|c|c|c|c|c|c|}
\hline Name & Country & Criteria & Year & Area $\left(\mathrm{hm}^{2}\right)$ & Biogeological Province & Rare species & Endemic species \\
\hline $\begin{array}{l}\text { The } \\
\text { Golden } \\
\text { Mountains } \\
\text { of Altai }\end{array}$ & $\begin{array}{l}\text { Russian } \\
\text { tion }\end{array}$ & $\mathrm{x}$ & 1983 & $1,611,457$ & $\begin{array}{l}\text { Altai Highlands } \\
(2.35 .11)\end{array}$ & $\begin{array}{l}\text { snow leopard Uncia uncia, } \\
\text { wolverine Gulo gulo, } \\
\text { eastern imperial eagle } \\
\text { Aquila heliaca }\end{array}$ & $\begin{array}{l}\text { Cisco teletsky, } C . \\
\text { pravdin }\end{array}$ \\
\hline $\begin{array}{l}\text { Uvs Nuur } \\
\text { Basin }\end{array}$ & $\begin{array}{l}\text { Mongolia/Russian } \\
\text { Federation }\end{array}$ & ix, $x$ & 2002 & 898,063 & $\begin{array}{l}\text { Mongolian-Manchurian } \\
\text { Steppe (2.30.11) / Altai } \\
\text { Highlands (2.35.11) }\end{array}$ & $\begin{array}{l}\text { snow leopard Uncia uncial, } \\
\text { Altai argali Ovis ammon, } \\
\text { musk deer Moschus mo- } \\
\text { schiferus, wolverine Gulo } \\
\text { gulo }\end{array}$ & $\begin{array}{l}\text { Astrogalus polozhinae, } \\
\text { Juncus salsuginous } \\
\text { ssp.tuvinicum, Stipa } \\
\text { barhanica, Asragalus } \\
\text { tuvinicus }\end{array}$ \\
\hline
\end{tabular}


Mountains and the major ecological combinations are desert, grasslands, coniferous forest, high-mountain tundra, broad-leaved forest, salt marsh and snow field, which show the transition from mountain forests to mountain grasslands.

To contrast Kanas with the Altai Mountains in Kazakstan, both are located on the south slope of the Altai Mountains and show similar biodiversity. With Kanas as the place where the highest peak of Altai Mountains stands, the glacier reserves, scale, landscape types and diversity exceed those of the mountains in Kazakstan. To contrast Kanas Lake with the representative lake of Markakol in Kazakstan, the former has advantages in terms of the scale, diversity and beauty of the natural landscape.

3.3.3 Comparison with World Heritage sites with exceptional natural beauty in the same latitude

From the perspective of natural beauty, there are 5 World Heritage sites that meet criteria vii at $45^{\circ}-55^{\circ} \mathrm{N}$ (Table 4). They have glaciers, snowfields, rivers, lakes, forests and grasslands, which can be compared with the Kanas. For example, the Bernese Alps is internationally famous for its scenery; the Canadian Rocky Mountain Parks are concentrated in famous mountain landscapes; Gros Morne National Park records the whole process of geological evolution of an oceanic basin and a continental plain, and is claimed to have the most spectacular scenery in eastern Canada; Waterton Glacier International Peace Park, owned by Canada and USA, is the most narrow part of the Rocky Mountains and is known as "The Crown of the Rocky Mountains”; Olympic National Park in USA is famous for its rainforest and combines a stormy coastline and the grand Olympic Mountain and, thus, is regarded as "A Park with Three Different Landscape". Compared with the above-mentioned heritage areas on the World Heritage List, the formers show the typical landscapes in the representative mountains of the main continents of Europe, North America and Asia, and Kanas, which shows the special landscapes in the Altai Mountains with its splendid scenery formed by a combination of the seasonal change of mountain forests and grasslands and rivers, lakes and bays, is irreplaceable. Compared with other similar regions in the Altai Mountains, such as Teletskoye Lake of the Golden Mountains of Altai, which is inscribed on the World Heritage List, and Markakol Lake in Kazakstan, Kanas has multiple landscapes which are intricately arranged and has more outstanding aesthetic values.

In 2009, there were 176 World Natural Heritage sites and 25 Mixed Cultural and Natural Heritage sites. The comparative analyses revealed that Kanas has three attributes that are unique in the world: (1) The

Table 4 Five World Heritage sites with exceptional natural beauty between $45^{\circ} 00^{\prime} \mathrm{N}$ to $55^{\circ} 00^{\prime} \mathrm{N}$

\begin{tabular}{|c|c|c|c|c|c|c|}
\hline Name & Country & Criteria & Year & $\begin{array}{l}\text { Latitude and longi- } \\
\text { tude }\end{array}$ & Altitude (m) & Features \\
\hline $\begin{array}{l}\text { Jun- } \\
\text { frau-Aletsch-Biets } \\
\text { chhorn }\end{array}$ & Switzerland & vii, viii, ix & $\begin{array}{l}2001 \\
2007\end{array}$ & $\begin{array}{c}46^{\circ} 30^{\prime} 00^{\prime \prime} \mathrm{N} \\
8^{\circ} 02^{\prime} 00^{\prime} \mathrm{E}\end{array}$ & $809-4,274$ & $\begin{array}{l}\text { The beauty of the Bernese Alps is internation- } \\
\text { ally famous. The site is the crest of a wall of } \\
\text { high mountains covered by the largest glaciated } \\
\text { area in the Alps }\end{array}$ \\
\hline $\begin{array}{l}\text { Canadian Rocky } \\
\text { Mountain Parks }\end{array}$ & Canada & vii, viii, ix & 1984 & $\begin{array}{c}50^{\circ} 34^{\prime}-53^{\circ} 28^{\prime} \mathrm{N}, \\
115^{\circ} 10^{\prime}-119^{\circ} 32^{\prime} \mathrm{W}\end{array}$ & $1,036-3,954$ & $\begin{array}{l}\text { They protect } 400 \mathrm{~km} \text { of forested mountain } \\
\text { landscape studded with dramatic snow-capped } \\
\text { peaks, glaciers, lakes, cascades, canyons and } \\
\text { caves }\end{array}$ \\
\hline $\begin{array}{l}\text { Gros Morne } \\
\text { National Park }\end{array}$ & Canada & vii, viii & 1987 & $\begin{array}{l}49^{\circ} 18^{\prime}-49^{\circ} 59^{\prime} \mathrm{N} \\
57^{\circ} 25^{\prime}-58^{\circ} 10^{\prime} \mathrm{W}\end{array}$ & $0-806$ & $\begin{array}{l}\text { Glacial action has resulted in spectacular scen- } \\
\text { ery, with coastal lowland, alpine plateau, fjords, } \\
\text { glacial valleys, sheer cliffs, waterfalls and many } \\
\text { pristine lakes }\end{array}$ \\
\hline $\begin{array}{l}\text { Waterton Glacier } \\
\text { International } \\
\text { Peace Park }\end{array}$ & $\begin{array}{l}\text { Canada/ } \\
\text { USA }\end{array}$ & vii, ix & 1995 & $\begin{array}{l}49^{\circ} 00^{\prime}-49^{\circ} 12^{\prime} \mathrm{N}, \\
113^{\circ} 40^{\prime}-114^{\circ} 10^{\prime} \mathrm{W}\end{array}$ & $972-3,190$ & $\begin{array}{l}\text { They are of exceptional scenic beauty and geo- } \\
\text { logic interest, with a striking overthrust fault } \\
\text { formation, proterozoic sediments and six species } \\
\text { of stromatolites }\end{array}$ \\
\hline $\begin{array}{l}\text { Olympic National } \\
\text { Park }\end{array}$ & USA & vii, ix & 1981 & $\begin{array}{c}47^{\circ} 29^{\prime}-48^{\circ} 16^{\prime} \mathrm{N}, \\
123^{\circ} 07^{\prime}-124^{\circ} 43^{\prime} \mathrm{W}\end{array}$ & $0-2,428$ & $\begin{array}{l}\text { It is an area of outstanding natural beauty com- } \\
\text { bining a stormy coastline and numerous offshore } \\
\text { islands with glacier-capped mountains and } \\
\text { alpine parklands rising above an extensive } \\
\text { mountain-slope rainforest }\end{array}$ \\
\hline
\end{tabular}


heritage site possesses mountain glaciers in the interior of Eurasia in the world's arid region and, thus, has irreplaceable scientific value for exploring the response of mountain ecosystems to global climatic change; (2) It is the ecotone of the Junggar temperate desert and Siberian flora and fauna, and also is an important habitat for snow leopard and lynx and other rare and endangered species. Thus, it is very significant for the protection of global biodiversity; and (3) the heritage site has integrated natural landscapes that are intricately assembled and it is an area of spectacular natural beauty.

\section{Conclusions}

On the basis of a comprehensive evaluation using the comparative geographic method of analysis in this paper, including the characteristics of the heritage of Kanas, analysis of the values of the heritage and their comparison with other similar World Natural Heritage sites, it is concluded that Kanas meets criteria vii, viii, ix and $x$ of World Natural Heritage.

(1) Criterion vii: "Sites nominated contain superlative natural phenomena or areas of exceptional natural beauty and aesthetic importance”. Many natural landscape types in the nominated site and their aesthetic values include the following: sublime glaciers and snow-covered peaks, colorful alpine meadows, grand granitic natural sculptures, dynamic atmospheric conditions, picturesque landscapes of rivers and lakes, and charming nomadic life and folk customs. These features combine to form unique aesthetic values that are second-to-none. The nominated heritage is a remarkable exemplification of the aesthetic value of the Altai Mountains, as well as of high mountains elsewhere in the world.

(2) Criterion viii: "Sites nominated should be outstanding examples representing major stages of the earth's history, including the record of life, significant on-going geological processes in the development of landforms, or significant geomorphic or physiographic features". Both various types of modern glaciers and complete landforms left by ancient glaciers, and the complete sequence of the glacial successional stages from the Quaternary Period can be found in Kanas. It is from here that we can study the motion of glaciers. It is an encyclopedia and natural museum of landforms of inland mountain glaciers.

(3) Criterion ix: "Sites nominated should be outstanding examples representing significant on-going ecological and biological processes in the evolution and development of terrestrial ecosystems and communities of plants and animals". The nominated heritage has preserved the complete sequence of the post-Quaternary evolution of glacial geography. There is prominent evidence of the three large glacial shrinkages and various types of vegetation that are at different evolutionary stages. Soils, vegetation and species succession are at different stages following glacial shrinking in the Altai Mountains. The nominated heritage is on the ecotone between the Junggar temperate desert and Siberian flora and fauna, and it is the corridor through which the flora and fauna of Xinjiang and Siberia are closely linked. The nominated area is a prominent place of transition and numerous rare species inhabit this region, which has played an important role in the evolution of flora and fauna, as well as in biodiversity protection.

(4) Criterion x: "Sites nominated should contain the most important and significant natural habitats for in-situ conservation of biological diversity, including those containing threatened species of outstanding universal value from the point of view of science or conservation". Kanas is located in the "Altai Highlands” Biogeographical Province and also represents the Altai-Sayan Montane Forests within the system of 200 global biota. Kanas is one of the habitats with the greatest biodiversity, where precious and endangered species, such as Orchis 1atifolia, Uncia uncia, Moschus moschiferus, etc. have their most important habitat.

As Kanas is a close neighbor of the world natural heritage of the "Golden Mountains of Altai" and the general conditions are similar between them, it is hard for Kanas to be listed alone as a world natural heritage. Therefore Kanas could be taken as an expansion of the “Golden Mountains of Altai”. There are two ways to apply for World Heritage designation. First, the area could be expanded with the heritage value unchanged; i.e. Kanas could meet criteria $\mathrm{x}$ to expand the "Golden Mountains of Altai”, which would enlarge the area of the "Golden Mountains of Altai" with Kanas included in it. Second, the heritage value of the "Golden 
Mountains of Altai" could be added and the area enlarged at the same time, i.e. Kanas could meet criteria vii, viii and ix which will be additional to criteria $\mathrm{x}$.

\section{Acknowledgements}

The research was funded by the Project of Science and Technology Plan of Xinjiang Uygur Autonomous Region

\section{References}

Chen F B, Zhao Y T. Basic problems of research on the super heritage resources - research status and project of world heritage and national parks in China. Journal of Mountain Science, 2004, 22(1): 1-6.

Chen F B, Zhao Y T, Lan L B, et al. Model of national park for management natural heritage of giant panda habitat in Jiajin mountains. Journal of Mountain Science, 2006, 24(6): 734-738.

Di F, Yang Z P, Liu X L, et al. Estimation on scenic beauty of tourist landscapes in natural heritage spots: the Kanas National Nature Reserve, Xinjiang, China. Chinese Geographical Science, 2010, 20(1): 59-65.

Di F, Yang Z P. Tourist Aesthetic Assessment and Conserved Management Mode of Natural Heritage Sites: A Case Study in the Kanas Nature Reserve, Xinjiang, China. Beijing: IEEE 2009 International Conference on Engineering Management and Service Sciences, 2009. $1-5$.

Dingwall P, Weighell T, Badman T. Geological World Heritage: A Global Framework. Paris: UNESCO World Heritage Centre, 2005 [2009-11-17]. http://whc.unesco.org.

Feng M. Landform and origin of Hanasi Lake, Altai Mountains. Journal of Glaciology and Geocryology, 1993, 15(4): 559-565.

Hazen $\mathrm{H}$. Of outstanding universal value: the challenge of scale in applying the World Heritage Convention at national parks in the US. Geoforum, 2008, 39: 252-264.

Li M M, Wu B H, Cai L P. Tourism development of World Heritage Sites in China: a geographic perspective. Tourism Management, 2008, 29: 308-319.

Liu H C, Wang L L. Traces of ancient glaciations and their division in the quaternary at the drainage basin of Halasi river in the Altai Shan of China. Journal of Glaciology and Cryopedology, 1983, 5(4): 39-47.

Liu H Y. Spirit of the World Heritage. Beijing: Huaxia Press, 2006. 113-115.

Liu X L, Yang Z P, Di F, et al. Tourism ecological security evaluation in nature heritage area-the case of Kanas Nature Reserve. Chinese Geographical Science, 2009, 19(3): 265-273.

Liu X L, Yang Z P, Xie T, et al. Analysis on the value of World Nature Heritage in Kanas and study on its conservation and development. Arid Zone Research, 2007, 24(5): 723-727.

Luo F, Zhong Y D, Wu Z H, et al. Tourism interpretive demand of
(200933128), the National Natural Science Foundation of China (40671057), and the Chinese Academy of Sciences Visiting Professorship for Senior International Scientists (2009S1-35). The authors gratefully acknowledge the help of Prof. James Thorsell and John Mackinnon from IUCN. The authors also appreciate the help of Prof. Ablimit and XingYou Zhao from Xinjiang Institute of Ecology and Geography, Chinese Academy of Sciences, and Prof. Ying Hai from Xinjiang Normal University.

visitors in World Natural Heritage site-take Wulingyuan as an example. Tourism Tribune, 2008, 23(8): 69-73.

Magin C. World Heritage Thematic Study for Central Asia. Paris: UNESCO World Heritage Centre, 2005[2009-11-17]. http://whcunesco.org.

Thorsell J, Hamilton L. A global overview of mountain protected areas on the world heritage list. Paris: UNESCO World Heritage Centre, 2002[2009-11-17]. http://whc.unesco.org.

Udvardy M D F. A classification of the biogeographical provinces of the world. Paris: UNESCO World Heritage Centre, 1975[2009-11-17]. http://whc.unesco.org.

UNESCO World Heritage Centre. Operational Guidelines for the Implementation of the World Heritage Convention. Paris: UNESCO World Heritage Centre, 2008[2009-11-17]. http://whc.unesco.org.

Wang L L, Liu C H, Kang X C, et al. Fundamental features of modern glaciers in the Altai Shan of China. Journal of Glaciology and Cryopedology, 1983, 5(4): 27-38.

Xu S L, Zhang Y H, Huang B J, et al. Comparative analysis on value of typical geological trace landscapes of Guangxi Fengshan Karst National Geopark. Journal of Mountain Science, 2009, 27(3): 373-380.

Yi C L, Cui Z J. Classification and sedimentary types of glacial lakes in the Halasi river catchment, the Altai mountains, Xinjiang. Oceanologia Et Limnologia Sinica, 1994, 25(5): 477-485.

Zhang C Z, Bao J G. A literature review of heritage tourism and heritage management abroad. Tourism Science, 2004, 18(4): 7-16.

Zhang C Z. Tourism and Heritage Protection. Tianjin: Nankai University Press, 2008. 1-20.

Zhang C Y, Xie N G. Principle of integrity and authenticity and protection of the World Heritage. Journal of Peking University: Philosophy and Social Sciences Edition, 2003, 40(2): 62-68.

Zhang R S, Jiang J F, Zhang X G. Current characters and development countermeasures of the World Natural Heritage Sites in China. Resources Science, 2006, 28(1): 186-191.

Zhao X, Li J H, Wang Y. Comparative study on the mountains on the world heritage list and suggestions about submission of Natural World Heritage in China. Geological Review, 2007, 53 (suppl.): 165-170. 